\title{
A comparison between fly ash- and basic oxygen furnace slag-modified gold mine tailings geopolymers
}

\author{
Thabo Falayi ${ }^{1,2}$ (D)
}

Received: 8 July 2019 / Accepted: 4 December 2019 / Published online: 16 December 2019

(c) The Author(s) 2019

\begin{abstract}
Fly ash (FA) and Basic oxygen furnace (BOF) slag were used to as additives in the geopolymerisation of gold mine tailings (GMT).The aim of the research was to determine the effects of the two additives on the strength formation and mechanism of metal immobilisation by modified GMT geopolymers. GMT, FA and BOF were mixed, respectively, and made into a paste with the addition of potassium hydroxide $(\mathrm{KOH})$ before curing at various conditions. 50\% replacement of GMT in the starting materials gave the highest unconfined compressive strength (UCS). The UCS for BOF-based geopolymer was 21.44 Mega Pascals (MPa), whilst the one for FA-based geopolymer was $12.98 \mathrm{MPa}$. The BOF-based geopolymer cured at lower temperature $\left(70{ }^{\circ} \mathrm{C}\right)$ as compared to the FA-based geopolymer $\left(90^{\circ} \mathrm{C}\right)$. The optimum $\mathrm{KOH}$ concentration was 10 and $15 \mathrm{M}$ for BOF- and FA-based geopolymers, respectively. BOF-based geopolymers resulted in the formation of calcium silicate hydrate $(\mathrm{CSH})$ phases which contributed to higher strength; whereas in FA-based geopolymers, no new structures were formed. BOF-based geopolymers resulted in over $94 \%$ iron $(\mathrm{Fe})$ immobilisation, whereas FA-based geopolymers had $76 \% \mathrm{Fe}$ immobilisation. Fe immobilisation was via incorporation into the $\mathrm{CSH}$ or geopolymer structure, whilst other metal immobilisations were thought to be via encapsulation. 12-month static leaching tests showed that the synthesised geopolymers posed insignificant environmental pollution threat for long-term use.
\end{abstract}

Keywords Gold mine tailings · Fly ash · Basic oxygen furnace slag · Geopolymer · Toxicity characteristic leaching procedure

\section{Introduction}

Geopolymers are synthesised when aluminosilicate materials are mixed with an alkali (usually $\mathrm{KOH}$ or $\mathrm{NaOH}$ ) and cured either at ambient or elevated temperatures $[1,2]$. The resulting pastes lead to dissolution of aluminate and silicate species into solution. This then leads to reorganistaion of $\mathrm{SiO}_{4}{ }^{4-}$ and $\mathrm{AlO}_{4}{ }^{5-}$ into tetrahedras resulting in a threedimensional amorphous monolith [3]. Geopolymers have been shown to have a high acid resistance; they develop strength fast and are capable of immobilising toxic metals [2,

Thabo Falayi

tfalayi@gmail.com

1 Department of Chemical Engineering, Malawi University of Science and Technology, Limbe, P.O. Box 5196, Blantyre, Malawi

2 Department of Civil Engineering Science, University of Johannesburg, Auckland Park, P.O. Box 524, Johannesburg 2006, South Africa
4]. Mine tailings are waste solid material resulting from the extraction of minerals from the mined ore body. Disposal of mine tailings has been shown to create environmental pollution and as such their stabilisation is of paramount importance $[5,6]$. Mine tailings have been shown to be rich in aluminium and silicon and hence can be used as precursors for the synthesis of geopolymers [7, 8].

Most mine tailings have been shown to be crystalline materials $[8,9]$ and hence require some form of modification or activation to enhance their activity. Metallurgical slags and fly ash are some of the incorporations that have been added to mine tailings to enhance their activity and increase the strength of synthesised geopolymers [7]. Incorporation of Ca-based (slags) material into geopolymers has been shown to improve mechanical strength of geopolymers [10]. The geopolymers formed with addition of slags to the starting materials result in the formation of geopolymer gel together with calcium silicate hydrate (CSH) gel, which further increases the strength of the geopolymer [11]. This is mainly because most slags are glassy 
materials with free $\mathrm{Ca}^{2+}$ ions making their activation relatively easy. The addition of 50\% FA to mine tailings has been shown to increase the UCS of the geopolymer by $233 \%$ when the paste is made using $15-\mathrm{M} \mathrm{NaOH}$ [7]. The maximum UCS gain was within 7 days with no significant strength gain after 7 days. One of the few studies where mine tailings have been modified with slags in the synthesis of geopolymers has shown that $50 \%$ addition of a slag resulted in a $96 \%$ increase in the UCS of the synthesised geopolymer [12]. These two studies then provide an impetus to the study of the effect of FA and BOF slag on GMT geopolymerisation, since the optimisation of any geopolymerisation process is also dependent on the source of the raw materials [13]. It has been shown the reutilisation of metallurgical waste is very low, with only China using $50 \%$ of its metallurgical waste [12]; whereas in South Africa, reuse of FA is below 6\% [14]. The paper, therefore, seeks to provide further use for BOF and FA in South Africa considering that South Africa currently has over 600000 tonnes of GMT [15]. There are a number of research on the use of granulated blast furnace slag [16-18] but very few focuses on BOF [19], and hence the need to do research on its use in the modification of GMT geopolymers.

South African gold mine tailings (GMT) have been successfully used to synthesise geopolymers but a number of disadvantages have been picked up [8]. The curing at elevated temperatures for 5 days have been shown to be energy intensive and not practicable for large uses of GMT. The highest unconfined compressive strength after a 5-day curing period was found to be $4.37 \mathrm{MPa}$.

There are a few studies available on the geopolymerisation of gold mine tailings [3, 8]. The energy intensive process of GMT geopolymerisation necessitates the need of incorporating additives which can help in the energy demand reduction. The mixture of GMT with other activators like granulated ground blast furnace slag (GGBFS) [3] has shown that geopolymerisation can take place at ambient temperature accompanied with a $400 \%$ increase in unconfined compressive strength. The geopolymerisation of GMT alone has shown to produce a monolith with a low strength (less than $7 \mathrm{MPa}$ ) $[8,20]$. The study also looks into metal leachability over time which few other studies have conducted. Of the few GMT geopolymer studies conducted, none also look into the environmental footprint of the geopolymers through leachability tests $[3,20]$.

The objectives of this research are to compare the effect of respective addition of FA and BOF slag on the properties of GMT geopolymers. The effect of different curing regimes was also investigated. The mechanism of heavy metal immobilisation was also investigated together with the type of geopolymer gel obtained from these two additions. Environmental footprint of the synthesised geopolymers was also investigated through 12-month-long static leaching tests.

\section{Materials}

GMT was taken from a mine dump in the West Rand $\left(26.3178^{\circ} \mathrm{S}, 27.6505^{\circ} \mathrm{E}\right)$ of Gauteng in South Africa. FA was taken from Camden power station in the province of Mpumalanga of South Africa. The BOF slag was taken from Arcelor Mittal steel Vanderbiljpark in South Africa. The $\mathrm{KOH}$ was supplied by Rochelle chemicals South Africa. The major oxides for GMT were $\mathrm{Fe}_{2} \mathrm{O}_{3}, \mathrm{~K}_{2} \mathrm{O}, \mathrm{SO}_{3}, \mathrm{SiO}_{2}, \mathrm{Al}_{2} \mathrm{O}_{3}$ and $\mathrm{MgO}$; for FA were $\mathrm{Al}_{2} \mathrm{O}_{3}, \mathrm{SiO}_{2}, \mathrm{~K}_{2} \mathrm{O}, \mathrm{CaO}$ and $\mathrm{TiO}_{2}$; whilst for BOF slag were $\mathrm{Fe}_{2} \mathrm{O} 3, \mathrm{~K}_{2} \mathrm{O}, \mathrm{SO}_{3}, \mathrm{SiO}_{2}, \mathrm{Al} 2 \mathrm{O}_{3}$, $\mathrm{CaO}$ and $\mathrm{MgO}$ [21] Table 1). The mineralogy of GMT was dominated by silica and pyrite, whilst FA was dominated by silica and mullite (Fig. 1). FA also showed the characteristic hump at around $25^{\circ}$ which indicated that the FA has an amorphous structure. BOF slag spectrum was not fully defined though the mineralogy was dominated by calcium silicate, calcium oxide, iron oxide and magnesium oxide. The obtaining XRD diffractogram for BOF slag was typical of slowly cooled BOF slag [22] and showed a slight hump

Table 1 XRF analysis of GMT, BOF slag and FA

\begin{tabular}{|c|c|c|c|}
\hline Constituent & $\operatorname{GMT}(\mathrm{m} / \mathrm{m})$ & $\mathrm{FA}(\mathrm{m} / \mathrm{m})$ & BOF slag $(\mathrm{m} / \mathrm{m})$ \\
\hline $\mathrm{Na}_{2} \mathrm{O}$ & 0.27 & 0.07 & 0.02 \\
\hline $\mathrm{MgO}$ & 5.16 & 0.62 & 3.32 \\
\hline $\mathrm{Al}_{2} \mathrm{O}_{3}$ & 6.98 & 25.34 & 6.63 \\
\hline $\mathrm{SiO}_{2}$ & 74.5 & 47.97 & 14.8 \\
\hline $\mathrm{P}_{2} \mathrm{O}_{5}$ & 0.083 & 0.67 & 0.05 \\
\hline $\mathrm{SO}_{3}$ & 3.05 & 1.33 & 1.1 \\
\hline $\mathrm{Cl}$ & 0.18 & 0.02 & - \\
\hline $\mathrm{K}_{2} \mathrm{O}$ & 1.26 & 1.26 & 0.02 \\
\hline $\mathrm{CaO}$ & 0.53 & 7.26 & 41.1 \\
\hline $\mathrm{TiO}_{2}$ & 0.44 & 2.71 & 0.3 \\
\hline $\mathrm{V}_{2} \mathrm{O}_{5}$ & 0.03 & 0.00 & - \\
\hline $\mathrm{Cr}_{2} \mathrm{O}_{3}$ & 0.12 & 0.06 & 0.01 \\
\hline $\mathrm{MnO}$ & 0.06 & 0.08 & 3.91 \\
\hline $\mathrm{Fe}_{2} \mathrm{O}_{3}$ & 7.03 & 10.01 & 27.3 \\
\hline $\mathrm{NiO}$ & 0.05 & 0.02 & 0.02 \\
\hline $\mathrm{CuO}$ & 0.01 & 0.02 & - \\
\hline $\mathrm{ZnO}$ & 0.02 & 0.02 & 0.01 \\
\hline $\mathrm{Rb}_{2} \mathrm{O}$ & 0.01 & 0.01 & - \\
\hline $\mathrm{Y}_{2} \mathrm{O}_{3}$ & 0.01 & 0.14 & 0.23 \\
\hline $\mathrm{ZrO}_{2}$ & 0.02 & 0.11 & - \\
\hline $\mathrm{Nb}_{2} \mathrm{O}_{5}$ & 0.01 & 0.00 & - \\
\hline $\mathrm{BaO}$ & 0.08 & 0.16 & - \\
\hline $\mathrm{PbO}$ & 0.02 & 0.13 & 0.18 \\
\hline $\mathrm{ThO}_{2}$ & 0.01 & 0.01 & 0.02 \\
\hline
\end{tabular}


Fig. 1 XRD analysis of GMT, FA and BOF slag ( $\mathrm{S}=$ Silica, $\mathrm{P}=$ Pyrite, $\mathrm{M}=$ Mullite, $\mathrm{H}=$ Haematite, $\mathrm{CS}=\mathrm{Cal}-$ cium silicate, $\mathrm{CaO}=$ Calcium oxide, $\mathrm{Fe}=$ Iron oxide,

$\mathrm{MgO}=$ Magnesium oxide)

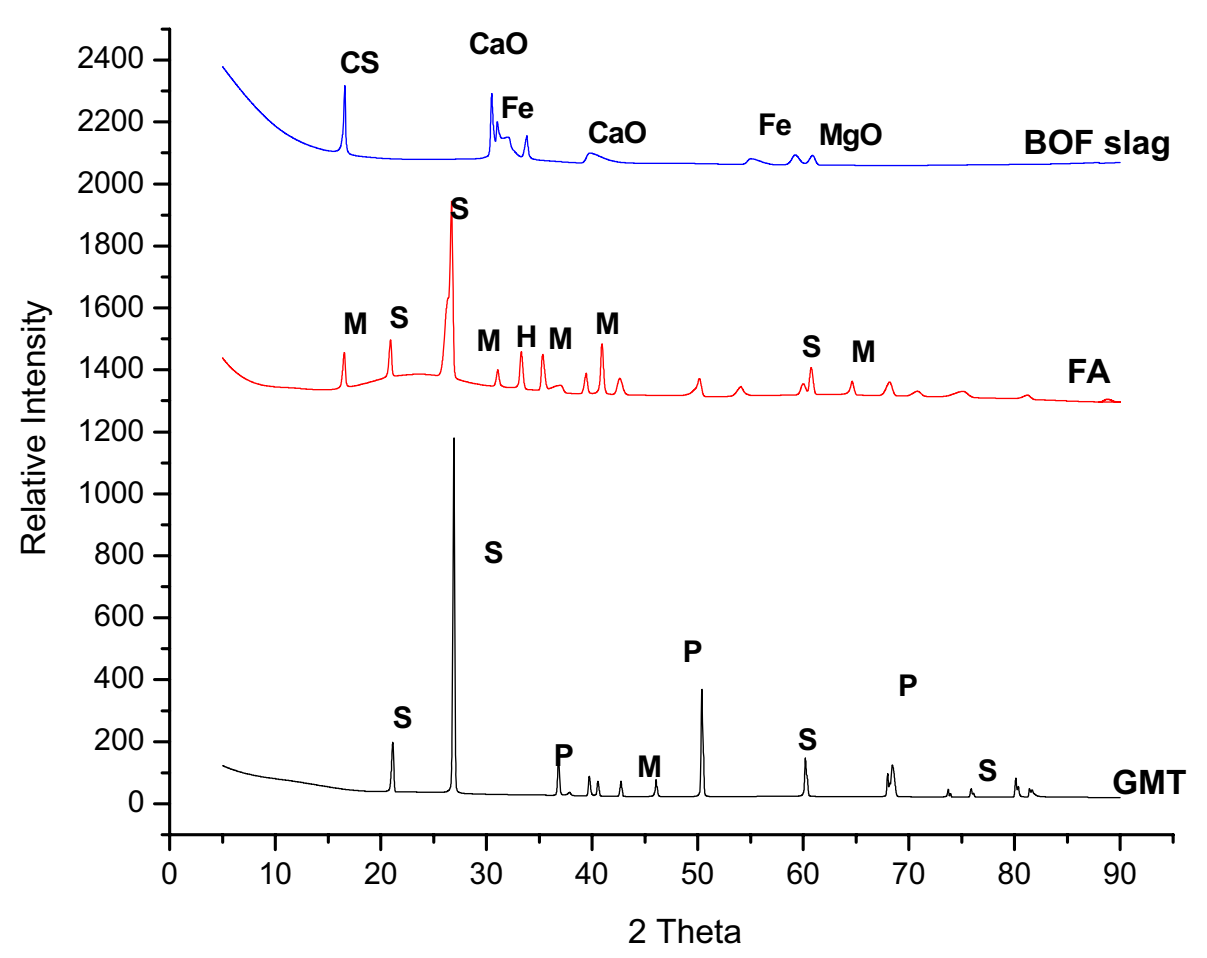

around $15^{\circ}$ showing that it also had an amorphous structure. GMT was coarser than BOF slag and FA with $16 \%, 8 \%$ and $0.5 \%$ of FA, BOF and GMT particles, respectively, having a grain size of clay (Fig. 2).

\section{Methods}

Figure 3 shows the Box Flow diagram of the methods used.

Oven-dried FA was mixed with oven-dried GMT at a mixture level of 0, 10, 30 and 50\% BOF slag (GMT, $10 \mathrm{BOF}$,
$30 \mathrm{BOF} \mathrm{BOF}$ and $50 \mathrm{BOF}$, respectively). $50 \%$ was chosen as the maximum so that the geopolymers synthesised would result in large volumes of GMT being used. An appropriate concentration of $\mathrm{KOH}$ was then added at $20 \%(\mathrm{v} / \mathrm{m})$ of the total solids. $\mathrm{KOH}$ was used as previous studies had shown that $\mathrm{KOH}$ was the best alkali for GMT-based geopolymers [8].The paste was then thoroughly mixed to form a smooth paste which was subsequently placed into a $50 \times 50 \times 50 \mathrm{~mm}$ mould. The paste in the mould was then placed in an oven at a particular temperature for 7 days. The conditions tested were the effect of $\mathrm{KOH}$ concentration $(5-15 \mathrm{M})$, curing

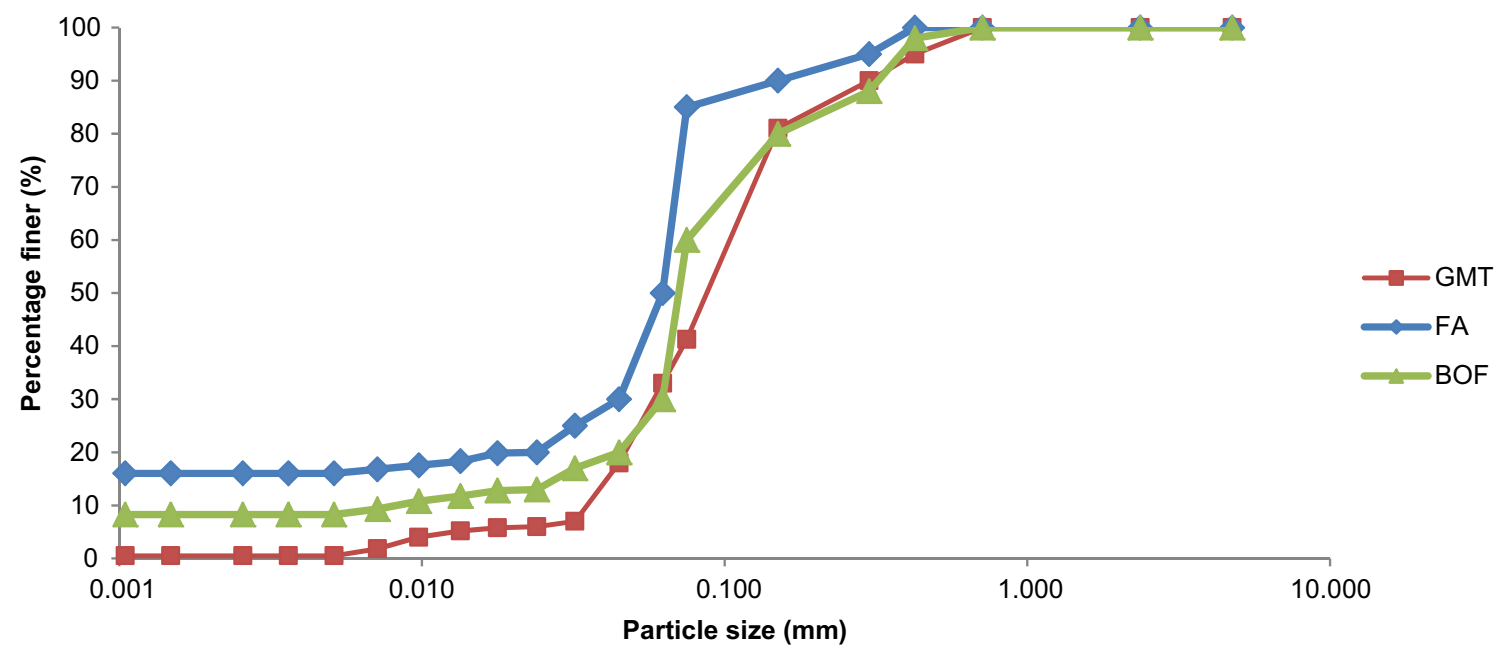

Fig. 2 Grain size analysis of GMT, BOF slag and FA 


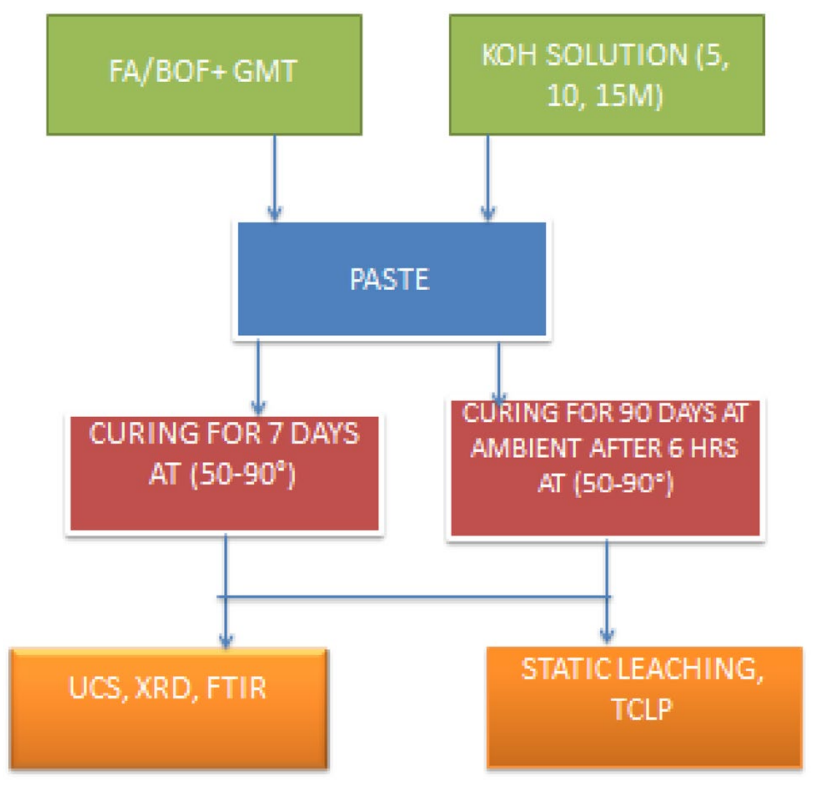

Fig. 3 Methodology Box flow diagram

temperature (50-90) and curing time (1-7 days). The above experiments were repeated with FA and a comparison was done. The unconfined compressive strength (UCS) test was conducted with the aid of a stress-controlled compression machine with a stress rate of $0.25 \mathrm{MPa} / \mathrm{s}$. The reported UCS was an average of three samples. The geopolymers which gave the highest UCS were then subjected to toxicity characteristic leaching procedure (TCLP) and durability tests. Durability was measured over a period of 90 days after curing. TCLP was done in accordance with the United States Environmental Protection Agency method [23]. The cured geopolymers without being crushed were placed in a column and completely covered with an extraction buffer of acetic acid and sodium acetate ( $\mathrm{pH} 4.93 \pm 0.05)$. The static extraction was left for 30 days. At the end of the 30 days, the extraction buffer was withdrawn completely before being acidified with nitric acid and subsequent metal analysis on the AAS. A fresh extraction buffer was also added to the soaked geopolymer. This routine was repeated for 12 months.

To reduce the energy consumption during curing, a number of curing experiments were carried out, where the paste was only cured at respective elevated temperatures for $1-6 \mathrm{~h}$, and immediately afterwards cured at ambient temperatures for $2,7,14,21,28,56$ and 90 days.

\section{Determination of CASH/CSH phase}

$5 \mathrm{~g}$ of milled geopolymer was placed $300 \mathrm{ml}$ of salicylic/ methanol solution ( $20 \mathrm{~g}$ of salicylic acid in $300 \mathrm{~mL}$ of methanol). The slurry was mixed for $2 \mathrm{~h}$. The slurry was allowed to settle for $15 \mathrm{~min}$ and then vacuum filtered using a $0.45-\mu \mathrm{m}$ filter and a Buchner funnel. The residue was washed with methanol, dried at $90{ }^{\circ} \mathrm{C}$ for $24 \mathrm{~h}$, and then weighed and recorded [24].

\section{Determination of geopolymer phase}

$1 \mathrm{~g}$ of milled geopolymer was added to $250 \mathrm{ml}$ of $\mathrm{HCl}$ acid solution $(5 \% \mathrm{v} / \mathrm{v})$. The slurry was stirred for $3 \mathrm{~h}$ after which the slurry was filtered with a Buchner filter and a $0.45-\mu \mathrm{m}$ filter and washed with reverse osmosis water. The insoluble reside was dried at $90{ }^{\circ} \mathrm{C}$ for $24 \mathrm{~h}$ and then weighed [25].

\section{Statistical analysis}

All reported results are an average of three geopolymer specimens. The error bars in all graphs at $95 \%$ confidence interval of the mean.

\section{Results and discussion}

\section{Effect of BOF slag/FA content and KOH concentration}

There was an increase in UCS of GMT and BOF-modified GMT geopolymers with an increase in $\mathrm{KOH}$ concentration from 5 to $10 \mathrm{M}$ followed by a decrease at $15 \mathrm{M}$ (Fig. 4). The increase in UCS was due to available hydroxyl ions to dissolve $\mathrm{Al}_{2} \mathrm{O}_{3}, \mathrm{SiO}_{2}$ and $\mathrm{CaO}$; whilst the decrease at $15 \mathrm{M}$ was due to an increase in free $\mathrm{Ca}^{2+}$ ions in solution due to diminished dissolution of $\mathrm{CaO}$ at high $\mathrm{pH}$ as shown in Table 2 for the $50 \mathrm{BOF}$ geopolymer. The free $\mathrm{Ca}^{2+}$ ions shows that they were not used in the formation of the $\mathrm{C}-\mathrm{A}-\mathrm{S}-\mathrm{H}$ gel leading to the reduction of strength as the $\mathrm{C}-\mathrm{A}-\mathrm{S}-\mathrm{H} / \mathrm{C}-\mathrm{S}-\mathrm{H}$ gel formed the bulk of the geopolymer. For the GMT geopolymer, the decrease at $15 \mathrm{M}$ was due to the paste becoming viscous and being difficult to work with. The FA-based

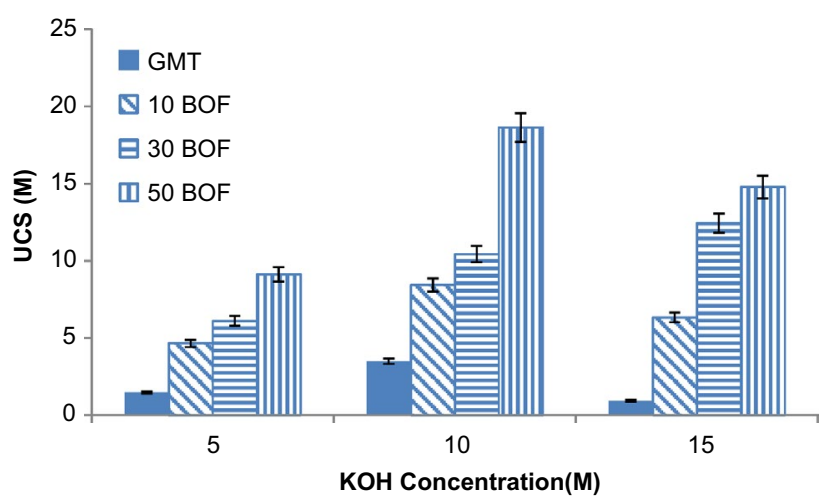

Fig. 4 Variation of UCS with amount of BOF slag and $\mathrm{KOH}$ concentration (Curing time of 3 days at $90{ }^{\circ} \mathrm{C}$ ) 
Table 2 Variation in free $\mathrm{Ca} 2+$ ions with $\mathrm{KOH}$ concentration for the 50 BOF geopolymer

\begin{tabular}{llll}
\hline KOH concentration & $5 \mathrm{M}$ & $10 \mathrm{M}$ & $15 \mathrm{M}$ \\
\hline Free $\mathrm{Ca} 2+(\mathrm{ppm})$ & 35 & 20 & 100 \\
\hline
\end{tabular}

geopolymers showed that there was an increase in UCS with an increase in $\mathrm{KOH}$ concentration up to $15 \mathrm{M}$. It has been shown that low Ca-based geopolymers require high $\mathrm{pH}$ for activation due to the need to break down the crystalline structures [26].

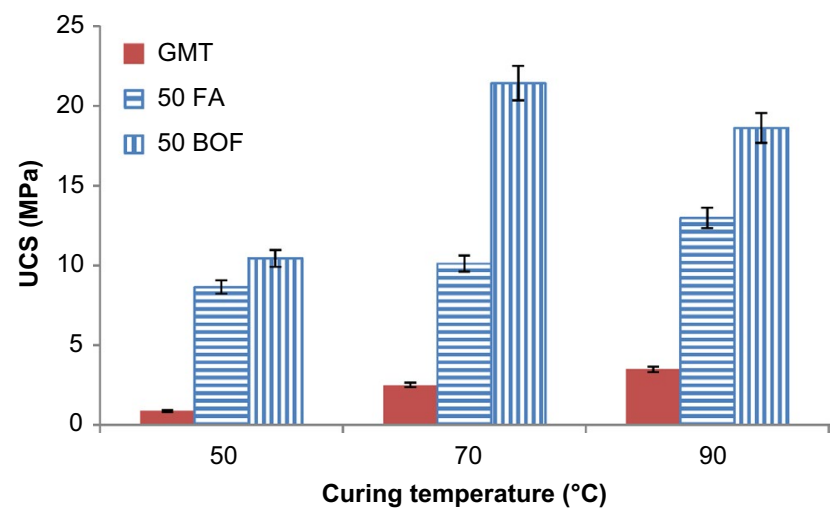

Fig. 5 Variation in UCS with curing temperature (Curing time 3 days, using $10 \mathrm{M} \mathrm{KOH}$ for BOF-modified geopolymer and $15 \mathrm{M}$ for FA-modified geopolymer)

\section{Effect of elevated curing temperature}

There was an increase in UCS with curing temperature for GMT- and FA-based geopolymers (Fig. 5). This was due to increase in energy provided for the mobility of molecules; however, for the BOF slag-based geopolymer, there was a decrease in UCS at $90{ }^{\circ} \mathrm{C}$. This was due to a decrease in solubility of $\mathrm{CaO}$ at elevated temperatures. For the BOFbased geopolymer, $\mathrm{CaO}$ solubility is critical since the $\mathrm{C}-\mathrm{A}-\mathrm{S}-\mathrm{H} / \mathrm{C}-\mathrm{S}-\mathrm{H}$ gel formed the bulk of the geopolymer as shown Fig. 6. It is worth noting that at any particular temperature, BOF slag-modified geopolymer had a higher UCS as compared to the FA-modified geopolymer. This was due to that BOF slag-modified geopolymer had C-A-S-H/C-S-H gel over and above the geopolymer gel which contributed to higher extent of geopolymerisation as shown in Fig. 6.

In an effort to reduce energy consumption during curing and try to make the geopolymer synthesis more practicable, curing was done at room temperature for 90 days, whilst other geopolymers were cured at $50-90{ }^{\circ} \mathrm{C}$ for $6 \mathrm{~h}$ and the remainder of the time to 90 days at room temperature. The BOF-based GMT geopolymer (Fig. 7) showed that ambient temperature curing was slow as the maximum UCS was reached after 56 days. A 6-h curing at $90{ }^{\circ} \mathrm{C}$ reached maximum UCS within 7 days and thereafter showed no significant increase in UCS. A 6-h curing at $50{ }^{\circ} \mathrm{C}$ proved to be the optimum with a UCS of 14.73 reached after 21 days. A 6-h curing at $50{ }^{\circ} \mathrm{C}$ gave the highest in that the moisture in the cast specimen was not lost as compared to higher
Fig. 6 XRD diffractogram of BOF-modified geopolymer (cured at $50{ }^{\circ} \mathrm{C}$ for $6 \mathrm{~h}$ and thereafter at ambient temperature for 21 days using $10 \mathrm{M}$ $\mathrm{KOH}$

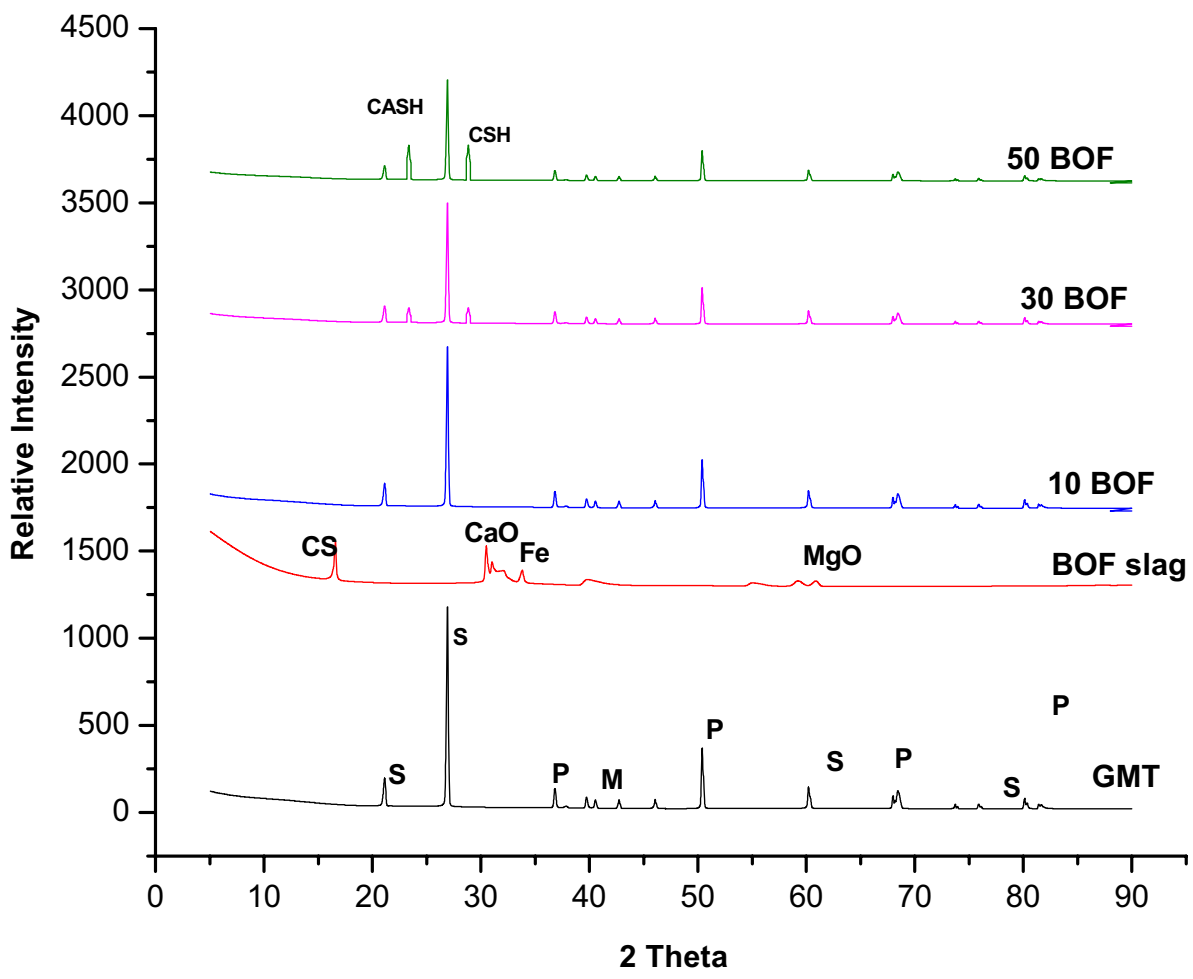


temperatures, therefore allowing geopolymerisation to continue during the rest of the ambient temperature curing. It is also known that the solubility of $\mathrm{CaOH}$ decreases with temperature leading to precipitation. For FA-modified GMT geopolymer (Fig. 8), a $90{ }^{\circ} \mathrm{C}, 6$-h curing followed by ambient temperature curing was the optimum giving a UCS of 6.77 MPa after 21 days. For both geopolymers at optimum curing regimes, 21 days was the optimum curing time with an insignificant UCS change afterwards. Figures 7 and 8 both show the importance of temperature in the development of strength for GMT-based geopolymers. A comparison of elevated temperature curing (Fig. 9) and mixed temperature curing regimes (Figs. 7 and 8 ) showed a $31 \%$ and $48 \%$ decrease in UCS for BOF slag- and FA-modified geopolymers, respectively, further emphasising the importance of temperature in curing of these geopolymers.

The $50 \%$ BOF geopolymer cured for $6 \mathrm{~h}$ at $50{ }^{\circ} \mathrm{C}$ (Fig. 7) met the minimum UCS requirements for use as a grade nonweathering brick [27]. All other 50 BOF geopolymers and 50 FA geopolymers met the minimum UCS requirements

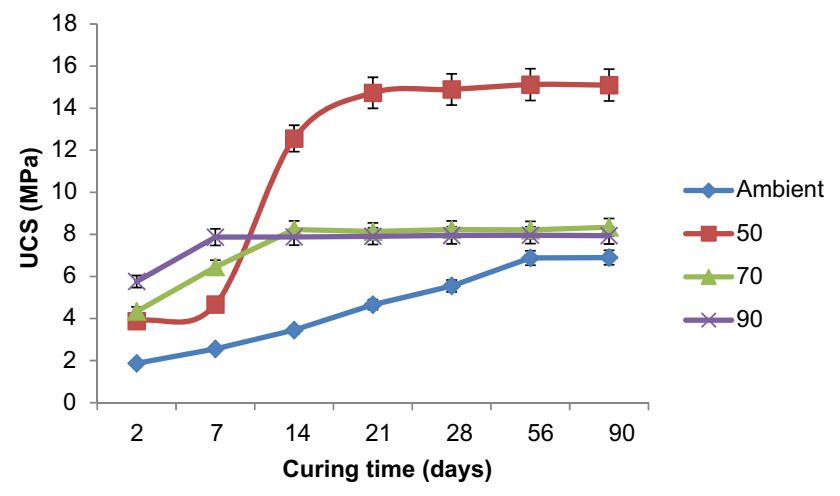

Fig. 7 Variation of UCS with time for 50 BOF slag geopolymer (elevated temperature curing was for $6 \mathrm{~h}$ only and there after the curing was at room temperature)

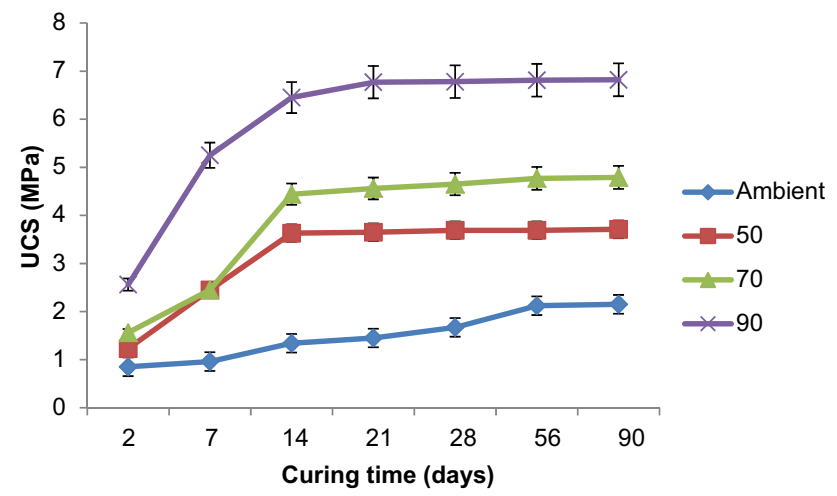

Fig. 8 Variation of UCS with time for 50 FA geopolymer (elevated temperature curing was for $6 \mathrm{~h}$ only and there after the curing was at room temperature) for use standard non-loading bricks with the exception of the 50 FA geopolymer cured at ambient temperature (Fig. 8) [28].

\section{XRD analysis of geopolymers}

The major difference between the 50 BOF geopolymer and the precursors of the geopolymer was the appearance of two new crystalline peaks at around 25 and $30^{\circ}$ (Fig. 6). These peaks represented $\mathrm{C}-\mathrm{A}-\mathrm{S}-\mathrm{H}$ and $\mathrm{C}-\mathrm{S}-\mathrm{H}$, respectively [29]. This accounted for the increase in strength of the geopolymers. Geopolymerisation was also associated with a decrease in the main silica peak which may indicate the dissolution of the crystalline phases under the alkaline conditions. Figure 10 shows the variation in phases with geopolymer type.

With an increase in BOF slag content in the starting materials, there was a corresponding increase in the CASH/ CSH phases. At above 30\% addition of BOF, the CASH/ $\mathrm{CSH}$ phases become more dominant than the geopolymer gel phase.

FA-modified GMT geopolymers did not result in the formation of new crystalline phases but resulted in the decrease of intensity of the crystalline peaks (Fig. 11). The main silica peak at around $27^{\circ}$ was split showing the aggressive nature of the alkaline environment and this is in agreement with the results obtained by Zhang et al. [7]. There was also a noticeable increase in the amorphous nature as evidenced by the upward shift of the baseline from about $10^{\circ}-20^{\circ}$ for the $50 \mathrm{FA}$ geopolymer as compared to the precursor materials.

\section{Ftir}

All precursor materials had the main band at around $1014 \mathrm{~cm}^{-1}$ (Fig. 12). This band represented the main chain structure which is the $\mathrm{TO} 4$ where $\mathrm{T}$ is $\mathrm{Al}$ or $\mathrm{Si}$ [30-32].

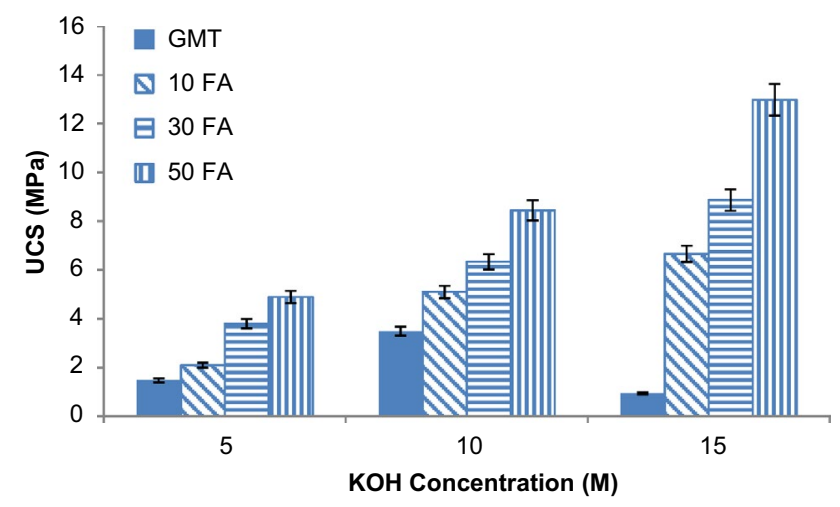

Fig. 9 Variation of UCS with amount of FA and $\mathrm{KOH}$ concentration (Curing time of 3 days at $90{ }^{\circ} \mathrm{C}$ ) 
The shifting of the main band to lower wavenumbers was a sign of geopolymerisation [7]. The 50 BOF geopolymer had the largest shift with the main band centred at $820 \mathrm{~cm}^{-1}$ from about $1014 \mathrm{~cm}^{-1}$, which was indicative of higher geopolymerisation and hence higher UCS than the 50 FA geopolymer. It, therefore, meant that the (SiQ) ${ }^{n}$ unit value for $\mathrm{n}$ was 0 as compared to 3 for the precursor materials. This indicated a highly amorphous structure for the geopolymer [33]. There was no significant shift for the 50 FA geopolymer; the gain in strength might, therefore, be due to the dissolution of silica and alumina and the gel formed becoming a glue to unreacted particles.

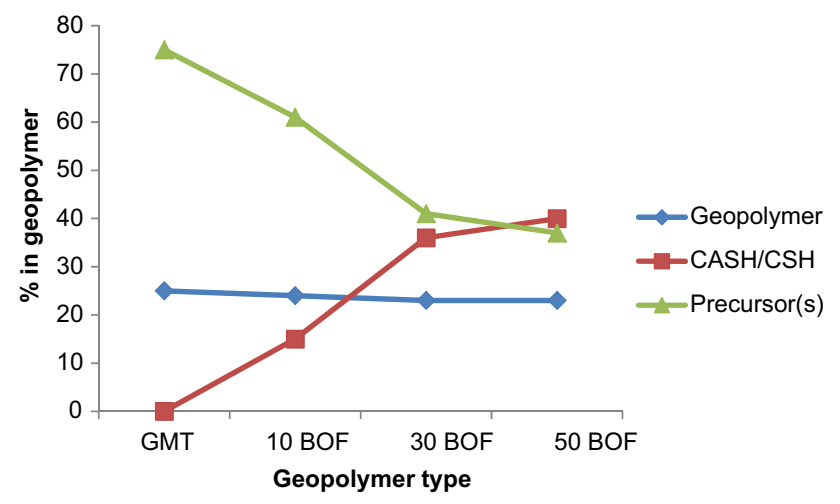

Fig. 10 Variation of phases with different types of geopolymers

\section{Sem}

The 50 BOF geopolymer showed more of the geopolymer phases (CASH/geopolymer gel) as compared to the $50 \mathrm{FA}$ geopolymer which showed a number of unreacted particles (Fig. 13). This then confirms the UCS analysis which showed that the 50 BOF geopolymer had a higher UCS than the 50 FA geopolymer. The 50 FA geopolymer was also characterised by loose contacts between individual particles, whereas the 50 BOF geopolymer was composed of tightly packed particles which also accounted for higher UCS. It has been shown that reduction in particle size/ regularity results in higher UCS due to more packing of particles [34].

\section{Tclp}

A TCLP analysis was done on the 50 FA and 50 BOF geopolymers and a comparison was done with the combined precursor materials.

FA-modified GMT geopolymer was not effective in the immobilisation Ni; whilst the BOF-modified GMT geopolymer was effective in the immobilisation of heavy metals with a $95 \%$ reduction in the leachability of Fe (Table 3). The reduction in $\mathrm{Fe}$ leachability in both geopolymers was due to the incorporation of $\mathrm{Fe}$ into the CASH/CSH structure or geopolymer structure (Figs. 14, 15) whilst other meal ions may be immobilised via encapsulation. The sum of all metal
Fig. 11 XRD diffractogram of FA-modified geopolymer (cured at $90^{\circ} \mathrm{C}$ for $6 \mathrm{~h}$ and thereafter at ambient temperature for 21 days using $15 \mathrm{M}$ $\mathrm{KOH}$

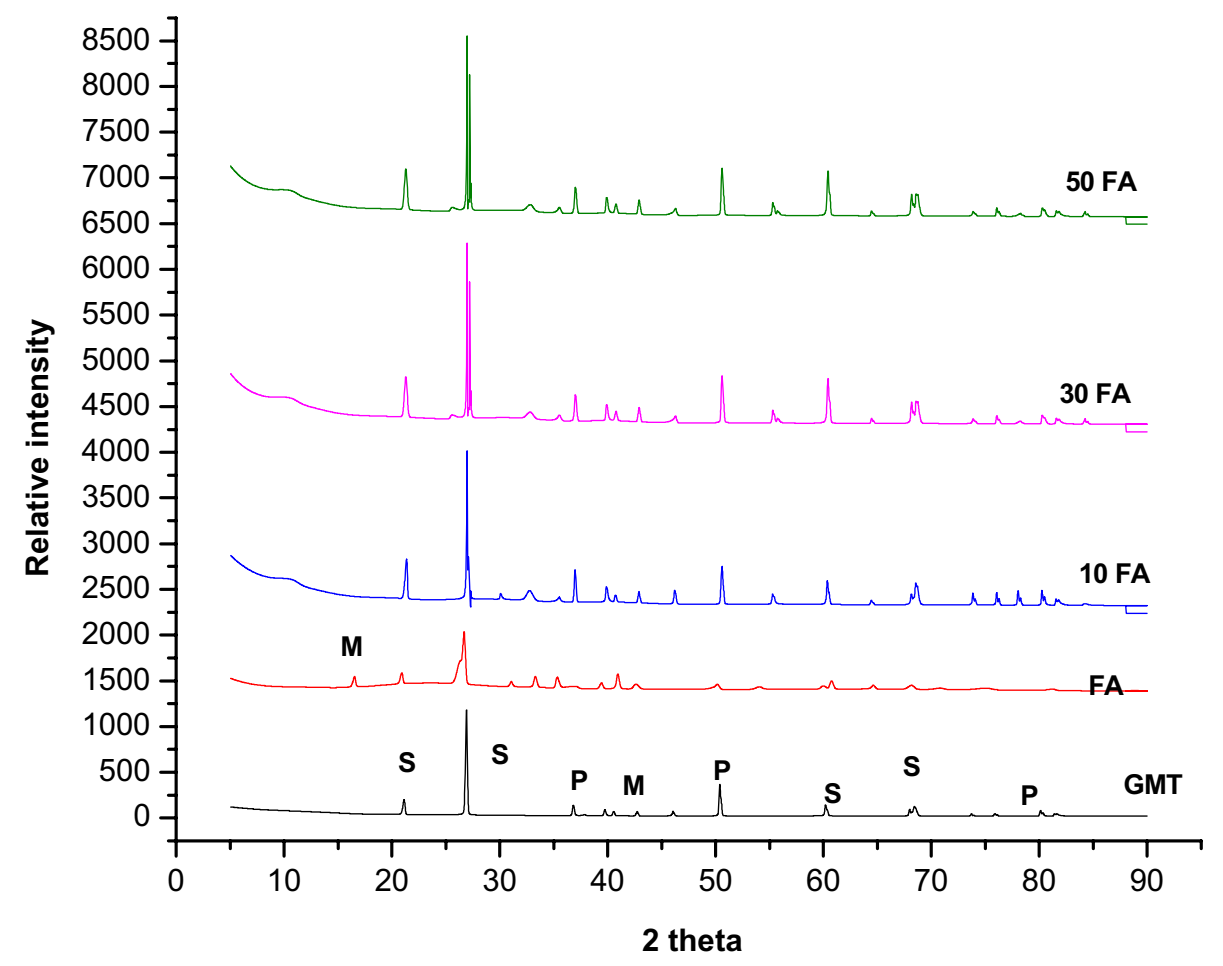


Fig. 12 FTIR analysis of geopolymers with precursor materials (50 FA-cured at $90^{\circ} \mathrm{C}$ for $6 \mathrm{~h}$ and thereafter at ambient temperature for 21 days using $15 \mathrm{M} \mathrm{KOH}$ (50 BOF-cured at $50{ }^{\circ} \mathrm{C}$ for $6 \mathrm{~h}$ and thereafter at ambient temperature for 21 days using $10 \mathrm{M} \mathrm{KOH}$ )
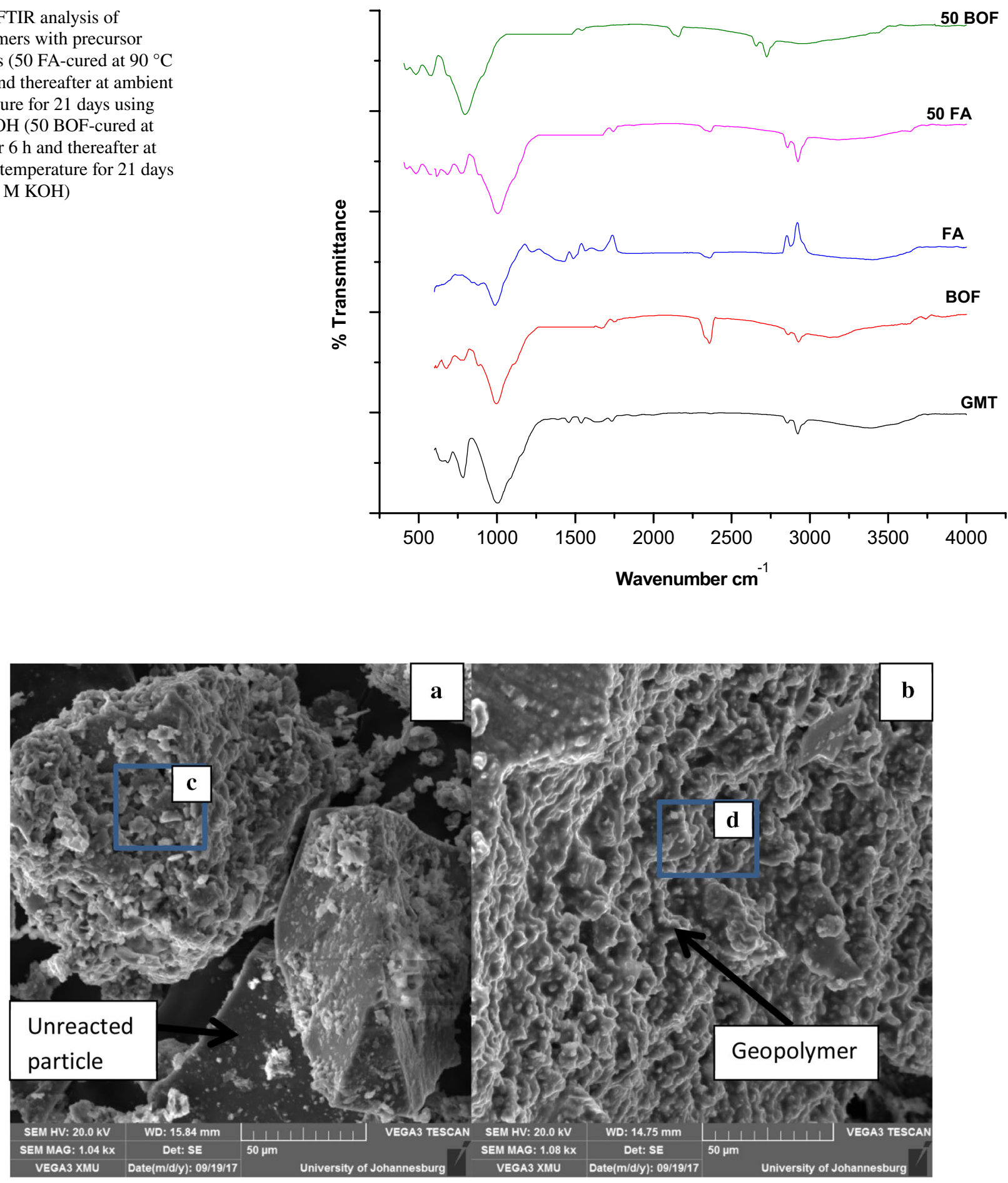

Fig. 13 SEM micrographs of a 50 FA geopolymer and b 50 BOF geopolymer, $\mathbf{c}$ and $\mathbf{d}$ are areas where EDX analysis was done

released over a period of 12 months was used to compute the metal release rates of the geopolymers. The release rates are shown in Table 4.

\section{Conclusion}

FA and BOF slag can be used to modify GMT-based geopolymers. BOF slag-modified GMT geopolymers cure at lower temperatures than FA-modified GMT geopolymers. 
Table 3 TCLP analysis

Fig. 14 EDX analysis of Fig. 13a area c
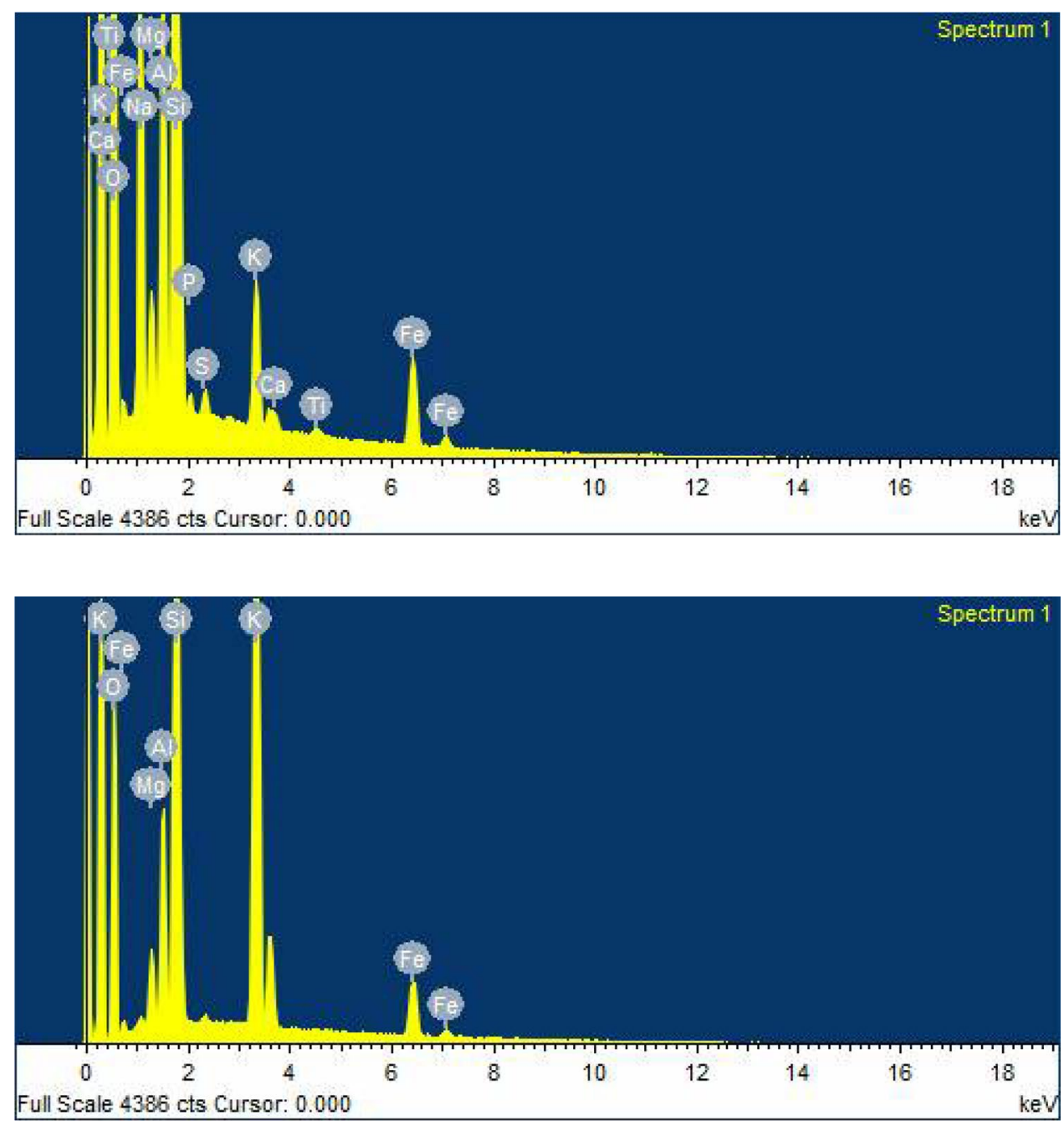

Fig. 15 EDX analysis of Fig. 13b area d

\begin{tabular}{lcccll}
\hline & $\begin{array}{l}\text { 50 FA precur- } \\
\text { sor material }\end{array}$ & $\begin{array}{l}\text { 50 FA geo- } \\
\text { polymer }\end{array}$ & $\begin{array}{l}\text { 50 BOF precur- } \\
\text { sor material }\end{array}$ & $\begin{array}{l}\text { 50 BOF } \\
\text { geopolymer }\end{array}$ & $\begin{array}{l}\text { Statutory limits (ppm) (South } \\
\text { African water Guideline 1996) }\end{array}$ \\
\hline $\mathrm{Fe}$ & 14.65 & 3.54 & 34.55 & 1.87 & 5 \\
$\mathrm{Ni}$ & 7.34 & 0.31 & 6.67 & 0.21 & 0.4 \\
$\mathrm{Cu}$ & 3.44 & 0.98 & 4.44 & 0.88 & 2 \\
$\mathrm{Mn}$ & 2.67 & 1.41 & 5.87 & 1.12 & 10 \\
$\mathrm{Zn}$ & 1.45 & 0.87 & 1.33 & 0.34 & 4 \\
Sulphates & 10,325 & 3100 & 10,489 & 2245 & 6000 \\
$\mathrm{pH}$ & 6.45 & 11.22 & 8.34 & 11.78 & - \\
\hline
\end{tabular}


environment as their 12-month static leaching tests were below acceptable limits. The use of FA and BOF slag to modify GMT geopolymers can provide avenues for use of these geopolymers as green civil engineering materials. BOF-modified GMT geopolymers were more effective in heavy metal immobilisation as compared to FA-based geopolymers.

Acknowledgements The funding has been received from University of Johannesburg with Grant No. 201323467.

Author contribution The author performed the laboratory work and was the primary and sole author of the paper.

Open Access This article is licensed under a Creative Commons Attribution 4.0 International License, which permits use, sharing, adaptation, distribution and reproduction in any medium or format, as long as you give appropriate credit to the original author(s) and the source, provide a link to the Creative Commons licence, and indicate if changes were made. The images or other third party material in this article are included in the article's Creative Commons licence, unless indicated otherwise in a credit line to the material. If material is not included in the article's Creative Commons licence and your intended use is not permitted by statutory regulation or exceeds the permitted use, you will need to obtain permission directly from the copyright holder. To view a copy of this licence, visit http://creativecommons.org/licenses/by/4.0/.

\section{References}

1. Van Deventer, J.S.J., Provis, J.L., Duxson, P., Lukey, G.C.: Technological, environmental and commercial drivers for the use of geopolymers in a sustainable materials industry. In: Kongoli, F., Reddy, R.G. (eds.) Proceedings of the 2006 TMS Fall Extraction and 1276 K. Komnitsas, D. Zaharaki/Minerals Engineering 20 (2007) 1261-1277 Processing Division: Sohn International Symposium, vol. 3, pp. 241-252, San Diego, California, 27-31 August (2006)

2. Luna, Y., Arenas, C.G., Cornejo, A., Leiva, C., Vilches, L.F., Fernandez-Pereira, C.: Recycling by-products from coal-fired power stations into different construction materials. Int. J. Energy Environ. Eng. 5, 387-397 (2014)

3. Kiventera, J., Golek, L., Yliniemi, J., Ferreira, V., Deja, J., Illikainen, M.: Utilization of sulphidic tailings from gold mine as raw materials in geopolymerisation. Int. J Min. Proc. 149, 104-110 (2016)

4. Majidi, B.: Geopolymer technology, from fundamentals to advanced applications: a review. Mater. Technol. 24, 79-87 (2009)

5. Monroy-Fernandez, M.G.: Acid rock drainage and metal leaching from mine waste material (tailings) of a $\mathrm{Pb}-\mathrm{Zn}-\mathrm{Ag}$ skarn deposit: environmental assessment through static and kinetic laboratory tests. Rev. Mex. Cienc. Geol. 24, 161-169 (2007)

6. De Souza, E., Dirige, A.P.: Assessment of the reliability of tailings dam structures by centrifuge modeling. In: Singhal, Mehrotra, (eds). Environmental issues and management of waste in energy and mineral production, pp. 257-64 (2000)

7. Zhang, L., Ahmari, S., Zhang, J.: Synthesis and characterization of fly ash modified mine tailings-based geopolymers. Constr. Build. Mater. 25, 3773-3781 (2011)
8. Falayi, T., Ntuli, F., Okonta, F.N.: Synthesis of a paste backfill geopolymer using pure acidic gold mine tailings. J. Solid Waste Technol. Manag. 44, 311-320 (2018)

9. Caballero, E., Sánchez, W., Ríos, C.: Synthesis of geopolymers from alkaline activation of gold mining wastes. Ingeniería y Competitividad 16, 317-330 (2014)

10. Bernal, S.A., Rodriguez, E.D., de Gutierrez, R.M., Gordillo, M., Provis, J.J.: Mechanical and thermal characterisation of geopolymers based on silicate-activated metakaolin/slag blends. J. Mater. Sci. 46, 5477-5486 (2011)

11. Puertas, F., Martınez-Ramırez, S., Alonso, S., Vázquez, T.: Alkaliactivated fly ash/slag cements: strength behaviour and hydration products. Cem. Concr. Res. 30, 1625-1632 (2000)

12. Ahmari, S., Parameswaran, K.L., Zhang, J.: Alkali activation of copper mine tailings and low calcium flash furnace copper smelter slag. J. Mater. Civil. Eng. 27, 1-11 (2015)

13. Komnitsas, K., Zaharaki, D., Vlachou, A., Bartzas, G., Galetakis, M.: Effect of synthesis parameters on quality of construction and demolition waste (CDW) geopolymers. Adv. Powder Technol. 26, 368-376 (2015)

14. Eskom and Ash management 2016. Available online: www.eskom .co.za/news/Pages/Feb20.aspx (Accessed 4/4/2018)

15. Winde, F.: Uranium pollution of the Wonderfonteinspruit, 19972008 part 1: uranium toxicity, regional background and miningrelated sources of uranium pollution. SA J. Radiol. 36, 239-256 (2010)

16. Burciaga-Diaz, O., Escalante-Garcia, J.: Structure, mechanisms of reaction and strength of an alkali-activated blast furnace slag. J. Am. Ceram. Soc. 96, 3939-3948 (2013)

17. Gao, X., Yu, Q.L., Brouwers, H.J.H.: Characterisation of alkali activated slag-fly ash blends containing nano-silica. Constr. Build. Mater. 98, 397-406 (2015)

18. Haha, M., Lothenbach, B.Le, Saout, G., Winnefeld, F.: Influence of slag chemistry on the hydration of alkali-activated blast furnace slag_-part I: effect of MgO. Cem. Concr. Res. 41, 955-963 (2011)

19. Liu, S., Hu, Q., Zhao, F., Chu, X.: Utilisation of steel slag, iron tailings and fly ash as aggregates to prepare a polymer modified water proof mortar with a core-shell styrene-acrylic copolymer as the modifier. Constr. Build. Mater. 72, 15-22 (2014)

20. Aseniero, J.P.A., Opiso, E.M., Banda, M.H.T., Tabelin, C.B.: Potential utilization of artisanal gold-mine tailings as geopolymeric source material: preliminary investigation. SN Appl. Sci. 1, 35 (2019)

21. Vassilev, S.V., Vassileva, C.G.: A new approach for the classification of coal fly ashes based on their origin, composition, properties, and behaviour. Fuel 86, 1490-1512 (2007)

22. Gautier, M., Poirier, J., Franceschini, G., Bodénan, F.: Influence of the cooling conditions on the nature and the size of the mineral phase in a basic oxygen furnace (BOF) slag. Déchets Sciences et Techniques 57, (2010)

23. USEPA: Toxicity characteristic leaching procedure. US Environmental Protection Agency, Washington, DC (1992)

24. Stutzman, P.: Guide for X-ray powder diffraction analysis of portland cement and clinker. NISTIR. 1996

25. Rees, C.A.: Mechanisms and kinetics of gel formation in geopolymers. The University of Melbourne 2007. PhD thesis

26. Provis, J.L.: Geopolymers and other alkali activated materials: why, how, and what. Mater. Struct. 47, 11-25 (2014)

27. ASTM C 62-17: Standard specification for building brick solid masonry units made from clay or shale. ASTM International (2011)

28. ASTM C 129-17: standard specification for nonloadbearing concrete masonry units. ASTM (2017)

29. Ezzat, M., Khater, H.M., El Nagar, A.M.: Enhanced characteristics of alkali activated slag/grog geopolymer bricks. Int. J. Sci. Eng. Res 7, 230-243 (2016) 
30. Djobo, J.N.W., Elimbi, A., Tchakoute, H.K., Kumar, S.: Reactivity of volcanic ash in alkaline medium, microstructural and strength characteristics of resulting geopolymers under different synthesis conditions. J. Mater. Sci. 51, 10301-10317 (2016)

31. Kumar, S., Kumar, R.: Mechanical activation of fly ash: effect on reaction, structure and properties of resulting geopolymer. Ceram. Int. 37, 33-541 (2011)

32. Khimich, N.N., Koptelova, L.A., Doronina, L.A., Drozdova, I.A.: Synthesis of monolithic silica gel in alkaline medium. Russ. J. Appl. Chem. 76, 1904-1908 (2011)

33. Zhang, Y., Sun, W., Li, Z.: Infrared spectroscopy study of structural nature of geopolymeric products. J. Wuhan Univ. Technol. Mater. Sci. Ed. 2008, 522-527 (2008)
34. Cho, G.C., Dodds, J., Santamarina, J.C.: Particle shape effects on packing density, stiffness, and strength: natural and crushed sands. J. Geotech. Geoenviron. 132, 591-602 (2006)

35. Panda, C.R., Mishra, K.K., Panda, K.C., Nayak, B.D., Nayak, B.B.: Environmental and technical assessment of ferrochrome slag as concrete aggregate material. Constr. Build. Mater. 49, 262-271 (2013)

Publisher's Note Springer Nature remains neutral with regard to jurisdictional claims in published maps and institutional affiliations. 